\title{
Sowing seeds of hope in California's fields of resistance to Pharm rice and Frankenfish
}

\author{
Dustin Mulvaney $^{1}$ and Anna Zivian ${ }^{2}$ \\ San Jose State University, USA \\ Ocean Conservancy, USA
}

\begin{abstract}
Absent the head of the household doing the right thing... we need the next strongest member of the household to do the right thing... the state government.

Former University of California representative, interview, July 15, 2005
\end{abstract}

\section{Introduction}

Controversies over genetically engineered organisms (GEOs) illustrate an important role for social movement actors in contemporary battles over risk, power, and governance. In California, anti-genetic engineering (GE) activism has played a substantial role in the development of strict sub-national regulations for biosafety risks from aquatic organisms and food crops that produce pharmaceuticals. Anti-GE activists framed the debate in terms of who takes risks and who benefits from these risky GEOs, enrolling those whose livelihoods would be most severely impacted. While fighting for precautionary politics on the risk terrain, many of the same activists are engaged in broader debates about the future of the food system. They are at once sowing seeds of resistance and hope for food system paradigm shifts. This paper explores two instances of sub-national regulation of GEOs in California-salmon and pharmaceutical rice-and explains the emergence of these precautionary policies, prospects for similar policies elsewhere, and what these engagements mean for broader food system change.

Debates about GEOs are deeply polarized. Anti-GE activists see dystopias of ecological ruin, unsafe food, and corporate control of agriculture that contrasts with proponents' promises of food cornucopias and efficient, productive, modern agricultural techniques. Some voices draw on biosafety science to argue that the novel techniques of GE augment uncertainties about ecological and food safety impacts. The conventional response to risk - environmental, human health, and economic - is to quantify risk probabilities, define acceptable levels, and determine an appropriate response to minimizing them. Nowhere in this narrow view of risk is there space to argue how particular technologies reinforce existing food systems paradigms, which also have important social and environmental dimensions.

It is in this sense that these cases exhibit the struggles for habitation found elsewhere in this special section of the Journal of Political Ecology, "Ecologies of Hope" (Rajan and Duncan 2013). These struggles imply a specific role and purpose for state authority. Karl Polanyi (1944) argued that efforts to create free markets were countered with efforts by the state to protect society from the consequences of free markets. He called this the double movement. Efforts to streamline the deployment of GEOs can be described in this free market context - commoditization, deregulation, and harmonization — and are countered by efforts to address the attendant risks to livelihoods and ecologies. The state's role as a conduit for corporate agriculture is countered by efforts to protect ecologies and livelihoods from corporate agriculture. But the role of the state is asymmetrical according to activists. Benefits accrue to a few multinational companies while risks are borne by the environment and local communities.

GEO deployment arguably has occurred at a more rapid pace than the scientific knowledge and regulatory framework necessary to understand and mitigate impacts. A key site of contestation is in the regulatory arena, where activists question whether a policy focus on containment-keeping GEOs where they are intended-is precautionary enough to protect ecosystems and society. Efforts to contain GEOs have been fraught with accidents, mistakes, and misfortune. Genes from research experiments have been discovered in the food system, while other GEOs have turned up in unintended food products. Activists refer to out-of-place GEOs as "genetic pollution" and argue that containment failures are inevitable. Activists aim to shift the narrative away from managing risk towards reconsidering whether risks are worth taking, moving the controversy from the realm of technical expertise to public deliberation. Asking, "is the risk worth taking?" invites salient questions: Who benefits? Who is at risk? What is at stake in GEO deployment? This opens the door to political economic concerns about the control of food system, agricultural industrialization, trade

\footnotetext{
${ }^{1}$ Dr. Dustin R. Mulvaney, Assistant Professor of Sustainable Energy Resources, Department of Environmental Studies, San Jose State University, 650 Pedro Ave. Ben Lomond, CA 95005, USA. dustin.mulvaney"at" sjsu.edu. This is the sixth paper in Rajan S.R. and Duncan C.A.M. (eds.) "Ecologies of Hope", special issue of Journal of Political Ecology 20: 70179.

${ }^{2}$ Dr. Anna Zivian, Senior Manager, Marine Spatial Planning, Ocean Conservancy 1300 19th St NW, Ste 800, Washington DC 20036, USA azivian "at" oceanconservancy.org.
} 
politics, the privatization of university research, and patents on living organisms. But these broader issues are obscured by the "objectivist risk discourse" (Heller 2003) that dominates queries about GEO deployment.

Yet the situation is not without contradiction. The very existence of a regulatory risk controversy often allows GEO opponents to use food and ecological safety as a surrogate to get at these broader issues. Risk discourses can be used as evidence of safety, or to illustrate potential harms. How these considerations influence decisions to deploy, deregulate, or contain GEOs often depends on who has the power ultimately to influence key decision-makers.

The argument against strong containment policies is that they impose unwarranted costs to industry and stifle innovation in emerging technologies. GEO advocates argue that the risks of not adopting the technology must be considered. Proponents present three primary arguments in favor of GEOs: (1) genetic engineering techniques offer a superior alternative to traditional plant and animal breeding; (2) they provide important agronomic benefits such as yield improvement or input reductions; and (3) in some cases they offer environmental benefits such as reduced chemical use or soil runoff. As for risks, proponents claim that thirty years of GEO field trials and fifteen years of consuming GE foods is sufficient proof that major environmental or human health problems are over-exaggerated. Proponents point to evidence of farmer adoption of GE cotton, corn, canola, and soybean seeds as an indicator of agronomic benefits. Finally, they suggest that addressing global food and agriculture problems will require the most advanced tools from agricultural biotechnology, a narrative embroidered with strong humanitarian overtones. The most widely told story of pro-poor agricultural biotechnology is of golden rice, a variety engineered for increased nutritional content that advocates claim will provide vital nutrients to the global poor (Potrykus 2001). Likewise, ecological modernization arguments are raised. Advocates also argue that GEOs are critical to efforts to sustain a "blue revolution" of farmed seafood that will be necessary to assure future protein sources in the face of land scarcity, a growing demand for seafood, and collapsing fisheries (Bisbee 1993).

Opponents of GEOs counter with a range of arguments including: (1) harm to human health, ecosystems, and agroecosystems; (2) negative economic impacts on agricultural sectors; (3) risk-benefit asymmetries; (4) concerns about agricultural industrialization and corporate control of the agrifood system; and (5) the need to maintain farmer and consumer choice and "right to know." There is also mistrust of the regulatory system (Lockie 2002). Food scares involving mad cow disease, E. coli, and salmonella have undermined confidence in regulators' ability to manage risks. The close ties and revolving doors between regulators and industry exacerbate this distrust and increase support for activists' calls for regulatory change.

This article describes how activists, regulators, and other key stakeholders in California worked to lower GEO contamination risks against these back-stories of governance, culture, and ecology. The cases touch down in two iconic California landscapes. The Sacramento Valley where the snow-capped Sierra, Cascade, and Trinity Alp mountain ranges drain into rice country, and the reaches of coast-bound rivers that comprise salmon habitat. These productive ecologies and agroecosystems were confronted by emerging GEO innovations during the 2000s, which enrolled various actors from fishermen and farmers to activists and concerned citizens, all voicing concerns about ecological, social, and economic impacts. To date, much of the GEO controversy has been abstracted to a scale that makes it difficult to weigh implications for communities and ecologies. This article details how these controversies played out at a higher resolution.

The article begins with a review of the social history and political economy of GEO governance. We outline the terrains on which opposition has been mobilized to date. We describe how despite the numerous aims of anti-GE activism, governance questions have focused on risk management at the federal level. As we describe in the subsequent sections, anti-GE activists have strategically moved to other venues to widen this scope. We next present two case studies of subnational regulation of transgenic salmon and "pharm" rice that show how new alliances and creative policy interventions addressed critical risks from these novel technologies. In these cases, precautionary policies were advocated, developed, and implemented to minimize potentially severe risks. We suggest why these policies emerged at these particular scales and places, concluding with prospects for replicating California's precautionary GEO policies elsewhere.

\section{The dystopia: GEOs and the political economy of risk}

GEOs have been rapidly adopted in food production since commercial introduction of GE crops and recombinant bovine growth hormone (rBGH) in the 1990s. But adoption has been rather narrow. Even though scores of organisms have been GE, only four major crops (soy, corn, canola, and cotton) with two traits (herbicide tolerance and pest resistance) comprise almost all GE crop acreage worldwide. While a handful of other GE crops are commercially available (for example, virus-resistant papaya in Hawaii), most products remain in the laboratory or field trials, where some are awaiting regulatory approval. We examine two GEOs awaiting regulatory approval to explore how social movements, industry, and sub-national government intervened in their commercialization. But first it is important to situate these particular mobilizations in the broader set of controversies that shape the social resistance to GEOs. 


\section{Biosafety: environmental and human health issues}

Genetic engineering uses techniques to splice and recombine DNA. Proponents hold that recombinant DNA (rDNA) technology is precise, safe, and increases the variety of tools and resources available to breeders (McGloughlin 2001). Other scientists suggest the movement of genes across species barriers warrants considerable caution in the face of novelty and unpredictability (Devlin et al. 2001). "Genetic engineering can create many more combinations of genes and new traits than can traditional breeding. This greatly enhanced novelty diminishes the ability to predict the safety of a transgenic organism on the basis of past experience" (Marvier 2001: 161). GEO proponents claim that existing regulations can nonetheless address any new issues that might arise. Rather than relying on post hoc and reactionary regulation, a coalition of scientists and anti-GE activists advocate precautionary approaches to anticipate, minimize, or prevent potential adverse effects (Traavik and Ching 2007).

\section{Agricultural industrialization}

Agricultural industrialization is itself a contentious issue. Productionist views on agricultural development underscore increases in yields and food production as critical to global food security, pointing to the success of the Green Revolution and avoided counterfactual famines (Borlaug 2000). Critics of the Green Revolution argue that reliance on high-yield seeds and imported agrochemicals widens the gap between rich and poor, instigating a wave of migration to urban centers, and exacerbating rural poverty and food insecurity (Griffin 1974; Pearse 1980). They blame the problem on industrial concentration, declining crop diversity, and top-down approaches to technological and economic development. They argue that agricultural technologies developed by multinational corporations and private foundations are insensitive to smallholder livelihoods and are driven by short-term profit-taking at the expense of a longer vision for sustainability and social justice.

\section{Commodification of living organisms: Whose risk? Whose reward?}

The first patents on living organisms in the USA emerged after several Supreme Court and Patent Office rulings in the 1980s opened the door to widespread commodification. Supporters of this trend argue patents are essential to stimulate innovation and protect investments. Patents on seeds pose problems in some agricultural commodities since they prevent farmers from seed saving, a traditional practice. Farmers may even be held liable for patent theft if they save and replant patented seed. The landmark Bowman vs. Monsanto case, concerning replanting of modified soybeans by an Indiana farmer, goes before the US Supreme Court in 2013 but is unresolved at the time of writing (Barnes 2013). It does not even matter how pollen or seed enters their field, as the verdict in the Percy Schmeiser case illustrates (Lee and Burrell 2002). Schmeiser, a Canadian canola farmer, was successfully sued by Monsanto for having RoundUp Ready canola present in his field despite his claims, true or not, that seeds came from passing trucks.

Anti-GE activists point out this uneven distribution of risk. Farmers must pay for patented crops they did not plant, but seed firms are not liable for a farmer's lost sales, markets, or contaminated seed stock. Farmers may seek redress through tort law. However, civil and criminal law is of questionable utility for farmers claiming financial losses; the few cases decided to date have ruled in favor of seed companies (Grossman 2002; Craik et al. 2007; Rodgers 2007). Benefits are unevenly shared as well as patent frameworks rewards scientists, universities, and firms with exclusive monopolies on plant genetic resources developed by generations of farmers (Mooney 1983). Patents have also shifted the research trajectory of agriculture and food production (Kloppenberg 2004) and continue to shape university research, leading some to ask whether universities can still function in the public interest (Kenney 1986; Lacy 2000).

\section{Revolving doors and the university-industrial complex}

As corporate interests spill into academic institutions and regulatory agencies, examples of the "revolving door" between industry and government are increasingly evident. For example, Supreme Court Justice Thomas was once a Monsanto corporate lawyer; Mickey Kantor, former US Trade Representative, became a member of the board of directors of Monsanto Corporation; and Michael Taylor, appointed senior advisor to the Food and Drug Administration (FDA) Commissioner on Food Safety in 2009, was formerly Monsanto's Vice President for Public Policy. American universities are also closely aligned with industry (Kenney 1986). These trends accelerated in the early 1980s with the Bayh-Dole and Stevenson-Wydler Acts, which fostered university-industry collaboration. This changed the shape and content of research, and raised questions about the broader role of the university in society (Bok 2003). The University of California, Berkeley built a \$25 million research center in 1998 funded by Novartis (now Syngenta). In addition, individual professors often have financial relationships - as funding recipients or even as board members with industry. One activist described these public-private relationships as an "erosion of the intellectual commons," as researchers acting in the public interest are slowly disappearing from the university (interview, 
August 2003). This is particularly important for agriculture, where public research has been the hallmark of land grant universities and cooperative extension.

\section{Past approaches: a social history of US GEO regulation}

\section{0s: containing GEO lab experiments}

Discussions about US GEO regulation began in the late 1960s with the first recombinant DNA experiments. When some scientists raised concerns about potential hazards from GEOs used in biomedical research (specifically, the spread of an epidemic pathogen with the insertion of mammalian viruses into $\mathrm{E}$. coli), they turned to a small number of molecular biologists familiar with the experiments to respond to the issue. A committee of experts convened at a number of professional society meetings and National Institutes of Health (NIH)-sponsored conferences to discuss how to deal with risks from rDNA experiments. Among its initial recommendations were a moratorium on more risky experiments and a call for the NIH to establish an advisory committee to oversee rDNA research, which it did in 1975 with the formation of the NIH rDNA Advisory Committee (RAC) (Berkeley et al. 1975; Wright 1994). The 1975 Asilomar Conference led to set of research guidelines based on a continuum of hazards, allowing certain types of experiments while precluding other, riskier ones (Krimsky 1982). These initially mandatory guidelines detailed technical containment protocols, but were made voluntary by 1979 after early experiments produced no known hazards.

Asilomar marked the beginning of US regulation of scientific research. It evaluated hazard potential against the assumption that benefits would likely emerge from GEO research. This justified advancing the research agenda, and kept scientists in control of future GEO policies. Perhaps most importantly, Asilomar focused the regulatory debate on GEO risks on containment, precluding broader issues of purpose, need, and ethics. While the NIH controls affected some research laboratories, by the 1980s molecular biology was becoming a commercial enterprise. The 1980 Diamond v. Chakrabarty Supreme Court ruling (Kevles 1998), and the Cohen-Boyer patent later that year (Smith Hughes 2001), set off a race to patent genetic engineering products and processes. Pharmaceutical and chemical producers invested heavily in the sector because of slow growth and rising energy costs in their own respective industries, while venture capital investments in boutique biotechnology startups were also growing, many spun out of university research. These political economic factors put university scientists working with NIH controls at a disadvantage compared to unregulated private sector research, so some partnered with the private sector. The new Reagan-era policies promoted the "university-industrial complex" (Kenney 1986), environmental deregulation, and economic competitiveness that would shape the commercial GEO production as experiments moved from laboratories into fields.

\section{0s: containing GEO risks through the "coordinated framework"}

The US government adopted a "science-based" approach to evaluating and regulating the commercialization of GEOs. Despite attempts by lawmakers to set up new rules and agencies, GEO regulation and management was vested in existing agencies through the 1986 Coordinated Framework for the Regulation of Biotechnology ("Coordinated Framework") (Office of Science and Technology Policy 1986). The Coordinated Framework aims to coordinate regulatory decisions and divide responsibilities among several agencies.

Under the Coordinated Framework, the US Department of Agriculture's Animal and Plant Health Inspection Service (USDA-APHIS), is responsible for "plants, seeds, plant pests, and certain GEOs containing genetic material from plant pests" (Uchtmann and Nelson 2000: 357). GE crops require APHIS approval for commercial planting, though most are granted "nonregulated" status. A National Research Council Committee (2002) noted improvement in the APHIS regulatory system, but found problems related to limitations on review triggers (some plants could pass under the radar); speed of reviews (decisions are required within 30 days of receiving the file); and permanence of deregulated status (once a plant is deregulated, USDA no longer maintains oversight of it). USDA-APHIS also oversees experimental field trials through a permitting process and field inspections to ensure containment protocols are followed. The USDA's own Office of Inspector General, however, found that monitoring and inspection of field trials were often inadequate (Liebert 2006).

The FDA, under the Food, Drug, and Cosmetic Act (FDCA), is responsible for regulating food additives, food, and animal drugs. Invoking the notion of "substantial equivalence," the FDA makes no distinction between most GE food and food produced through other breeding techniques. This approach sees GE food as substantially equivalent to non-GE food when their chemical and physical characteristics are similar.

The Environmental Protection Agency (EPA) regulates toxic substances on authority from the Federal Insecticide, Fungicide, and Rodenticide Act, the FDCA, the Toxic Substances Control Act, the Food Quality Protection Act, and the Plant Pest Act. This covers plants engineered to produce their own pesticides or other 
toxics. The EPA sets safety tolerances and evaluates the non-target impacts of pesticide-producing plant tissues. The agency is also responsible for insect resistance management plans where plant-producing pesticides might cause insects to evolve pesticide resistance.

\section{0s: Governance in the era of GEO commercialization}

Shared responsibility for GEO regulatory oversight does not always result in intuitively sensible divisions of authority. For example, there are potential problems regulating transgenic fish and livestock under the Coordinated Framework. "...Public policy regulating distribution and final use of transgenic animals is not well defined, with a number of federal agencies responsible for particular aspects of such oversight, but none with overall responsibility as a lead agency" (Kapuscinski and Hallerman 1990: 3). Concerns over regulating GE fish are exacerbated by questions about regulatory competence. The FDA has chosen to regulate one particular transgenic Atlantic salmon on the basis that its engineered growth hormone makes it analogous to a new animal drug. Yet the FDA does not have the expertise to make ecological risk decisions (Logar and Pollock 2005).

Additionally, the Coordinated Framework provides no way to determine whether GEOs, once released, have caused harm. "No agency...monitors deregulated GEOs for ecological impact. Critics question whether USDA-APHIS's mandate to protect the interests of US agriculture make it an appropriate agency for environmental risk regulation, and also question whether there are gaps in the regulatory framework for environmental monitoring..." (Ten Eyck et al. 2001: 308). Likewise, without labels on GE foods, there is no way to trace adverse health reactions.

\section{Alternative approaches}

In the last decade, activists and academic researchers have increasingly proposed alternative strategies for addressing biosafety and socio-economic risks. Rather than relying on post hoc regulation and mitigation, coalitions of scientists and anti-GE activists advocate precautionary approaches to anticipate, minimize, or prevent potential adverse effects. These approaches include stricter permitting processes, moratoria, or outright bans; mandatory labeling so consumers can choose whether to purchase GE products; traceability requirements so that health impacts can be monitored; liability laws to protect farmers against GEO contamination; and restrictions on open-air experimental field trials and commercial plantings.

\section{Practicing precaution}

The precautionary principle asserts that when scientific knowledge about the consequences of an activity is uncertain, but a realistic possibility of severe or irreversible harm exists, the activity should be avoided. The precautionary principle has a range of definitions from strong to weak, from implicit to explicit, from vague to specific. One common definition is found in the United Nations' Rio Declaration on Environment and Development (UNEP 1992): "Where there are threats of serious or irreversible damage, lack of full scientific certainty shall not be used as a reason for postponing cost-effective measures to prevent environmental degradation."

Precautionary principle formulations typically include several important elements: avoiding severe or irreversible consequences; accepting that actions should protect ecosystem and human health even in absence of complete knowledge; shifting the burden of proof from those exposed to risks to those benefiting; pollution prevention rather than "end-of-pipe" solutions; dissemination of information and consideration of a wide range of alternatives; and democratic decision making and broad public participation (Raffensperger and Tickner 1999).

Containment of GEOs is the precautionary measured used to prevent genetic pollution. Physical containment and/or biological confinement can reduce the risks of transgene escape (Daniell 2002; National Research Council 2004). Physical containment utilizes temporal and spatial isolation to reduce pollen flow and seed movement. Biological containment strategies focus on limiting transgene expression, inducing male sterility, chloroplast transformation, and with fish, by using chemical- or pressure-induced techniques such as triploidy (triploid fish have three sets of chromosomes and are unable to reproduce).

However, there are challenges in achieving reliable bioconfinement and containment. It is not possible to guarantee $100 \%$ triploidy success (Devlin et al. 2006), let alone prevent all sources of human error. Containment measures are at best imperfect answers to concerns about GEO escape. Containment can lower risks, but cannot eliminate them. Marvier and Van Acker (2005) contend that "... (1) the movement of transgenes beyond their intended destinations is a virtual certainty; and (2) it is unlikely that transgenes can be retracted once they have escaped" (p.103). The National Research Council (2004) calls for redundancy and multiple containment techniques; monitoring; plans to deal with containment failure; and flexibility to apply different rules to different organisms, including prohibitions (e.g., not using food crops to produce potentially toxic products). 
Incidents of genetic pollution (see Figure 1) have intensified scrutiny of GEO containment regulations. Activists point to these failures as they call for stronger regulation and have created a website dedicated to "record[ing] all incidents of contamination arising from the intentional or accidental release of genetically modified (GM) organisms" (GeneWatch UK \& Greenpeace International 2010). Activists use these genetic pollution incidents as evidence to legitimately claim inadequate GEO oversight.

\begin{tabular}{|c|c|c|c|}
\hline Event & Date & Product & Circumstance/consequences \\
\hline $\begin{array}{l}\text { Unauthorized flax found } \\
\text { in several European } \\
\text { countries }\end{array}$ & 2009 & Flax & $\begin{array}{l}\text { A GE flax that has been illegal to grow in Canada since 2001, } \\
\text { due to concerns about loss of export markets, was found in a } \\
\text { consignment to Belgium that had been distributed throughout } \\
\text { Europe; Canadian flax prices fell over } 34 \% \text { even before the } \\
\text { contamination was confirmed. }\end{array}$ \\
\hline $\begin{array}{l}\text { Unapproved rice variety } \\
\text { widespread in rice } \\
\text { exports }\end{array}$ & $\begin{array}{l}2006- \\
2009\end{array}$ & Rice & $\begin{array}{l}\text { Bayer's LLRice62, 601, and } 604 \text { (grown in the US) discovered } \\
\text { in rice exports; some LL varieties subsequently granted } \\
\text { approval in US. US rice futures prices dropped sharply after } \\
\text { discovery of contamination. }\end{array}$ \\
\hline $\begin{array}{l}\text { Tomato seeds sent to } \\
\text { scientific labs }\end{array}$ & 2003 & Tomato & $\begin{array}{l}\text { Petoseed/Seminis (now Monsanto) provided undocumented } \\
\text { seed to University of California researchers, who sent it } \\
\text { abroad. }\end{array}$ \\
\hline $\begin{array}{l}\text { Pig-vaccine corn found } \\
\text { in soy products }\end{array}$ & 2002 & Corn/soy & $\begin{array}{l}\text { Prodigene experimental pharm corn mixed with soy intended } \\
\text { for human consumption; contaminated soy destroyed, } \\
\text { Prodigene paid for destroyed soy and fined. }\end{array}$ \\
\hline $\begin{array}{l}\text { Syngenta distributed } \\
\text { Bt10 maize }\end{array}$ & $\begin{array}{l}2001- \\
2004\end{array}$ & Corn & $\begin{array}{l}\text { Bt10 maize had not received regulatory authorization for } \\
\text { commercialization at the time it was sold/distributed by } \\
\text { Syngenta. }\end{array}$ \\
\hline $\begin{array}{l}\text { Pharm pigs' progeny } \\
\text { sold to livestock dealer }\end{array}$ & $\begin{array}{l}2001- \\
2003\end{array}$ & Pigs & $\begin{array}{l}\text { Offspring of GE pigs modified with growth hormone to } \\
\text { increase milk production sold without authorization; unclear } \\
\text { whether they inherited introduced traits. }\end{array}$ \\
\hline $\begin{array}{l}\text { Starlink corn discovered } \\
\text { in processed corn } \\
\text { products }\end{array}$ & 2000 & Corn & $\begin{array}{l}\text { Starlink, authorized only for animal feed, discovered in a } \\
\text { variety of human food products - Aventis forced to stop } \\
\text { selling StarLink; US government purchased seed from seed } \\
\text { companies to remove it from market. }\end{array}$ \\
\hline
\end{tabular}

Figure 1: Selected Genetic Pollution Events 2000-2009. Source: Greenpeace and GeneWatch UK (2009).

Efforts to improve the Coordinated Framework have met little success. Monitoring and follow-up are suspect or inadequate where they are needed such as to verify compliance with, for example, rules requiring refuges of non-GE crops to slow development of pest resistance to Bt (Cleveland and Soleri 2005). Subnational governments have provided a new venue for precautionary GEO containment discussions. A broad coalition of activists, farmers, and scientists has prompted state and local government to fill the perceived Federal regulatory gaps in GEO oversight. City, county, and state regulatory and legislative activities are directed at a variety of concerns held by many sides of the GEO debate (Pew Initiative on Food and Biotechnology 2003). Figure 2 shows the extent of subnational regulatory efforts. 


\begin{tabular}{|c|l|l|}
\hline Subnational governments & \multicolumn{1}{|c|}{ Location } & \multicolumn{1}{|c|}{ Regulation type } \\
\hline Municipalities & $\begin{array}{l}\text { 85+ towns in Vermont; 31+ } \\
\text { municipalities in Massachusetts; } \\
\text { two each in Maine, New } \\
\begin{array}{l}\text { Hampshire; several municipalities } \\
\text { in other states }\end{array}\end{array}$ & $\begin{array}{l}\text { Resolutions on GE crops, } \\
\text { including labeling, moratoria/GE- } \\
\text { free zones, and requirements for } \\
\text { liability legislation }\end{array}$ \\
\hline Counties & $\begin{array}{l}\text { Four counties in California, with } \\
\text { additional counties considering } \\
\text { action; } \\
\text { Two counties in Hawaii } \\
\text { Boulder County, Colorado }\end{array}$ & $\begin{array}{l}\text { Moratoria on commercial GE } \\
\text { crops }\end{array}$ \\
\hline States & $\begin{array}{l}\text { Ban on GE taro } \\
\text { Prohibits growing GEOs on city- } \\
\text { owned property }\end{array}$ \\
\hline ME, MI, MN, MS, OR, WA) & $\begin{array}{l}\text { Transgenic aquaculture permitting } \\
\text { requirements and/or bans }\end{array}$ \\
& Vermont & $\begin{array}{l}\text { Permitting process for "plant } \\
\text { pests"; seed labeling legislation }\end{array}$ \\
Maine & GE-free labeling authority \\
Minnesota & $\begin{array}{l}\text { Permitting, monitoring, } \\
\text { enforcement authority for GE } \\
\text { crops }\end{array}$ \\
\hline
\end{tabular}

Figure 2: Examples of US subnational governmental actions on GEOs. Sources: Taylor et al. 2004, OCA, Lobbywatch.org

\section{Turning to subnational regulation}

Subnational regulatory efforts have occurred several times in the tumultuous history of GEO politics. The earliest rDNA research involving E. Coli and the simian virus - the topics of discussion at Asilomarspurred local ordinances restricting research in number of cities, including Cambridge, Ann Arbor, San Diego, New Haven, and Princeton (Krimsky 1982; Weiner 2001). After the rDNA Advisory Committee authorized the outdoor field trials of the bacterium Pseudomonas syringae in 1986, some local governments sought to control or prevent open-air experiments. Advanced Genetic Sciences (AGS) faced stiff opposition to the release of their "ice-minus" bacterium (P. syringae) in Monterey County, California, which they hoped to test in the Salinas Valley. When the company was caught conducting unapproved outdoor experiments in Oakland, California, they were fined $\$ 13,000$ by the EPA, and an earlier 45-day moratorium was extended for year by the Monterey County Board of Supervisors (Newell-McGloughlin and Re 2006). Concerns about unauthorized and unmonitored use prompted the Monterey County board of supervisors to pass a short-term moratorium on GE bacterium field trials and to direct the County Health Department to perform a risk assessment on its health and safety implications in 1986 (Brown and Goble 1990). This incited the controversy in Modoc County where University of California, Berkeley Professor Steven Lindow's application to field test a similar GE bacterium (also P. syringae) also faced local opposition, resulting in a non-binding resolution opposing the experiment from the Modoc County board of supervisors (NewellMcGloughlin and Re 2006). After AGS moved to Contra Costa County California in 1987, their experimental plots were uprooted by anti-GE activists, and a similar uprooting took place in the Modoc County plots a month later (Newell-McGloughlin and Re 2006).

The adoption of the Coordinated Framework in June 1986 momentarily quelled concerns about GEO release, but recent contamination incidents, broader awareness, and fears of market loss have again raised questions about the adequacy of federal oversight and prompted recent local actions (Taylor et al. 2004). Activists and officials cite a lack of federal action and competence as a primary motivation for encouraging their representatives to act. One nongovernmental organization (NGO) scientist said state and local governments were "one area where you could actually do something..." and added "state action has an impact on industry" (interview, April 2005). Eleven states have passed legislation regulating transgenic aquaculture (including all four states on the Pacific coast, from Alaska to California), and a number of states have adopted statewide reporting requirements for GEOs. Vermont requires labeling for GE seeds; Maine allows labeling for GE-free products. Four California counties have enacted countywide bans after Mendocino and Marin 
voters passed citizen-initiated ballot measures, and Santa Cruz and Trinity county supervisors passed similar bans directly through county ordinances (Geniella 2004; Organic Consumers Association 2004). At the municipal level, Berkeley, California passed a resolution calling for a federal GEO ban (Berkeley City Council 1999). Legislative and regulatory efforts in California fits into this model of looking beyond - or circumventing - federal policy in addressing GEO risks. The cases we review are two actions from California, where activists, industry groups, and subnational government officials used state policies and laws to address GEO risks.

\section{California's fields and streams of resistance}

The role of California, and the ways in which it constitutes a geophysical, socioeconomic, and political habitation, is key to the two case studies that follow. California's anti-GE activists took a stand against imposition of an economic model that threatened their place and the local economies that were imbricated in and co-constructed with the ecological, cultural, and social environments in which they are based.

California also has a history as an environmental forerunner, a place willing to try new laws and regulations to protect the health, safety, and welfare of its residents. Its economic prominence creates both need and opportunity for new regulation. Perhaps nowhere else in the United States has the Polanyian double movement been more evident. California has long had a strong focus on economic development, based on trade and a free market - and made possible by the abundant natural and human resources in the state. But California's economic liberalism and grown have been matched by its history of protective regulation for environmental and human health. California is a forerunner in economic development just as much as it is in environmental legislation - in fact, the two are intrinsically linked. Thus the place has helped create the driving factors for both economic experimentation and growth as well as the social and environmental activism unwanted externalities caused by that growth engender.

California's history as well as its natural and agricultural resources are central to the case studies that follow. Its agricultural production provides food not only for much of the US but also for foreign export markets, a critical factor in the first case study of genetically engineered rice. In addition, its long coastline and many rivers mean that fisheries, and especially the local wild salmon fishery, have long been an important part of California's economy. Entire towns grew up around the fishing and canning industry, and while fisheries no longer contribute substantially to the state economy, they remain regionally important. Salmon remains an iconographic presence socially, culturally, and traditionally, and threats to wild fisheries provoke passionate responses.

These two case studies, of rice and fish, analyze two movements for 'habitation' - they are stories of people trying to maintain culture in a particular place by acting in that place. At the same time, the actors in these cases are using habitation, their connection to a place, to change how they interact in national and international contexts as well. The actors' understanding of their role, their place, the cultural, economic, and social contexts in which they are operating, is part of why these two cases are examples of ecologies of hope (Rajan and Duncan 2013). They are experiments in democratic action and decision making, with solutions reached by coalitions of activists who worked within institutions to give form to their resistance to genetically engineered organisms that they saw as inimical to their cultural and economic past and future. We follow the case studies by examining they ways in which these two cases in California are representative of other ecologies of hope, what the particular context meant to how they unfolded, and whether they might translate into other contexts.

\section{Growing against the grain: food as pharmaceuticals factories}

The setting for the first case study is Northern California's Sacramento Valley. Here the rain and snow that fall on the mountains of the Sierra Nevada, Southern Cascades, and Trinity Alps drain into California's rice country. Unlike most of California, water here is relatively abundant as it is seasonally impounded behind Federal and state water infrastructure projects, including the Shasta, Oroville, and Trinity dams. The hot, dry summers and cool, wet winters help make this the most productive place to grow rice in the world, and rice has been grown here since the early 1900s. Many rice growers in this region have deep family roots, farming the same land for generations.

California has one the most productive rice landscapes in the world. It is partly sustained by Farm Bill subsidies that double the crop's value and the state and Federal water projects that subsidize the thirsty crop. Rice sales also depend on profitable, WTO-mandated, rice sales to Japan for about 50\% of their $\$ 500$ million annual revenues. Concerns about these critical export markets became a focal point in the debate about the commercial deployment of GE rice in California. Anti-GE activists and concerned rice growers were able to push pharm rice out of the state's valuable rice producing region.

Wary rice growers, buyers committed to sourcing non-GE rice, a receptive public, and politically savvy activists helped facilitate the adoption of a key piece of state-level legislation in 2000, and later challenged the first decision made under this framework in 2004. This case examines the claim that the 
Californian Rice Certification Act is a model for managing the economic risks with GE crops for its focus on planting and handling requirements (Taylor et al. 2004). We will explain how this policy emerged, how it was utilized in practice, and the prospects for introducing similar policies elsewhere.

GEOs designed to produce pharmaceuticals—so called "pharm" crops-are being heralded as a new frontier in biomedicine. The seeds of food crops happen to make very good factories for making proteins. But using food crops raises the potential for medicines or vaccines to accidentally end up in the food supply. Unlike other GE crops, "plant made pharmaceuticals" (PMPs) unquestionably present food safety risks because pharm crops are specifically designed to affect human health. Foods contaminated with traits from pharm crops would clearly not be considered "substantially equivalent" to conventional foods. Hence, PMPs require strict containment. Seeds can be improperly handled or labeled might be planted or processed unbeknownst to a grower or buyer. "Volunteers" might emerge from seed leftover from a previous year's harvest, or seed transported to nearby fields by wildlife, water, or wind. Pollen from a pharm crop could hybridize with nearby crops if they are similar species.

Opposing the use of food crops for pharmaceutical production are public interest groups such as the Center for Food Safety, Union of Concerned Scientists, and the Action Group on Erosion, Technology, and Control. While these organizations are familiar faces on the anti-GE front, their concerns are echoed by voices that typically tout the benefits from GEOs. The journal Nature Biotechnology, generally sympathetic to GEOs, published an editorial urging caution with PMP deployment (Editorial 2004). They emphasized that an episode of food crop contamination with pharmaceuticals could have serious public health implications, and could add to the already negative public perception of GEOs, slowing broader deployment.

Pharm crops field trials have been conducted in California since 1997-notably a GE rice variety produced by Ventria Bioscience - but no pharm or industrial crops are commercially grown. Pharm crop field trials are planted on limited acreage with more regulatory oversight by the USDA-APHIS than other GE crops. According to regulators, all pharm crop sites receive at least one site visit and typically require much larger buffer distances (Marvier and 2007).

These pharm rice field trials, along with the federal approval of herbicide tolerant GE rice from AgrEvo (now owned by Bayer), prompted the rice industry to pursue the California Rice Certification Act of 2000 (CRCA) as a means to regulate rice varieties with traits that could have negative impacts. While the legislation does not mention GE rice explicitly, the introduction of GE rice would satisfy the standard of impact to marketability set out in the CRCA. According to a CRC member, "We have a policy in place that speaks very clearly to the fact that GE rice should not be planted until such time as there is commercial acceptance" (interview, December 2005). The CRCA gives the industry unprecedented control over the planting and handling of new rice varieties with "traits of economic significance." Since up to 50\% of California rice is exported to countries with strict GEO policies, the industry was concerned that sales to entire markets could be lost. The CRCA requires that the California Rice Commission (CRC) - the political organization that oversees industry regulatory matters - and the developer of a new rice variety work together on planting and handling guidelines, which must be approved by the California Department of Food and Agriculture (CDFA).

In December 2003, after seven seasons of field trials, Ventria Bioscience officially notified the CRC that it intended to commercially produce rice engineered with the recombinant human proteins r-lactoferrin (Lactavia $^{\mathrm{TM}}$ ) and r-lysozyme (Lysomin ${ }^{\mathrm{TM}}$ ). Both proteins are recombinant versions of proteins found in breast milk, saliva, and tears, and have anti-fungal, anti-viral, and anti-bacterial properties, with lactoferrin also having iron-binding properties. Ventria used their proprietary ExpressTec ${ }^{\mathrm{TM}}$ technology platform, developed in collaboration with the University of California, to express these proteins in rice. Alternative means for producing these proteins use mammalian cell culture in bioreactors. But costly bioreactors are not easily scalable to increase output, and are difficult to manage for quality control, the outputs often tainted with mammalian blood plasma.

Ventria planned to grow rice in isolated, open fields; harvest, mill, and pulverize the rice; and extract the proteins to fortify infant formula because of the proteins' anti-diarrhetic properties (Nandi et al. 2002). Since dehydration is a leading cause of infant mortality in developing countries, Ventria's spokespeople made claims about the human health and equity implications of their proprietary technology. According to Ventria CEO, Scott Deeter: "We're solving world problems....we want to save two million kids a year. That's what gets us out of bed in the morning" (Pamer 2004: 13). These sentiments were echoed in Congressional testimony where Deeter spoke of a low-cost and safer technological solution to the conventional systems for producing these proteins; he made similar claims about how these proteins could play in suppressing the "silent enemy attacking US troops" during "Operation Iraqi Freedom" (Deeter 2005). Ventria hoped that these claims would support the application in the regulatory review.

Ventria's application faced significant opposition from anti-GE activists at multiple scales across Northern California to Washington, DC. The Center for Food Safety (CFS) and the Union of Concerned Scientists in particular had been focusing on the pharm crop issue, both preparing white papers on the topic (Andow et al. 2004). With news of Ventria's intentions, CFS staff collected scientific evidence for biosafety 
risks and did a commodity chain "power" analysis to identify allies and opponents. They looked at downstream buyers of the rice and whether or not those buyers had explicit policies on GE inputs, or how they might be pressured to. This process would prove to be critical in convincing regulators of the risks and to making important alliances with downstream buyers and key rice growers.

Meanwhile, several prominent California rice growers were already voicing concern about the adoption of any GEO rice, much less pharm rice. They were anxious that pharm rice could damage buyers' perceptions of the integrity and quality of California rice. Not only is much of California's rice harvest to sold Japan, Taiwan, and South Korea, where GE rice can be blocked and shipped back; much is also sold domestically as organic, or to companies with strict policies against using GEOs, including large buyers like Budweiser and Trader Joe's. GE pharm rice is unquestionably a variety with economic significance.

When new rice varieties trigger a review under the CRCA, the CRC assembles a panel of eleven rice industry experts comprised of millers, growers, and distributors, plant scientists, and a University of California representative. This panel represents rice industry interests, and works closely with the applicant to develop special handling and planting procedures to ensure that rice varieties with traits of economic significance do not commingle with other rice. Field-level containment protocols include spatial and temporal crop isolation, monitoring for crop volunteers that might take root in the field or field margins, and restricting some seeding and handling practices. For example, in the Ventria case, seeding rice by airplane, a practice widely used in California, was prohibited to avoid seed scattering into unintended places. Nets were required to discourage waterfowl, common visitors to California rice fields which sit along the Pacific Flyway; birds aid seed dispersal (Holt Mueller and van der Valk 2002). Dedicated harvesting, washing, and milling equipment would be required to avoid potential commingling with Ventria's rice. In March 2004, the CRC panel, by a 6-5 vote, approved Ventria's planting and handling protocols. Key was restricting production to ten Southern California counties, far removed from the Sacramento Valley where over 95\% of California rice is grown (See Figure 3). The CRC panel assumed that keeping Ventria's rice spatially segregated would eliminate the risk of losing lucrative export markets. Before the new rules could become law, the California's Secretary of Agriculture had ten days to accept or reject the planting and handling protocols.

Meanwhile, anti-GE activists actively campaigned against GE rice. The coalition of food and farming activists known as "the Californians for a GE-Free Agriculture" had already been working on an anti-GE rice campaign since 2002. CFS, a central pillar of that coalition, submitted numerous letters to the California Agriculture Secretary highlighting the risks of pharm rice. They provided risk research including a summary of genetic pollution incidents as well as a brief documenting potential avenues for GE rice to enter fields and the food system.

In the ten-day period between the CRC vote and the CDFA deadline to approve or reject Ventria's application, the CDFA received a letter from the Japanese Rice Retailers Association suggesting that they would no longer purchase California rice if there was even a perception that it was contaminated. The potential loss of the industry's single largest market in Japan was already a concern of rice growers, and this letter validated the issue's significance. The CDFA is obligated to protect the interests of California growers, so there was a persuasive argument for denying the planting protocol. CFS also agreed that Ventria's permit should be denied because it was filed as emergency regulatory review and had yet to obtain the required Federal permits. Ventria applied for an emergency approval because the planting season was fast approaching, but such a short period for review did not provide sufficient opportunity for public comment, or, as argued by the activists, time for adequate agency review. As the ten-day window expired, the CDFA ruled against Ventria and the CRC protocols. The secretary stated, "it is very clear that many wish to comment prior to any planting made possible in any way by implementation of this regulation" (cited in Taylor et al. 2004: 96). So despite initial support from the industry organization, commercial pharm rice production was halted.

This decision was primarily influenced by two factors. First, industry concerns about volatile export markets in Japan, Taiwan, and South Korea loomed large. It prompted the industry to pass the CRCA to shift the risk burden from growers and handlers to seed developers. Later, market concerns drove some growers to be outspoken on the pharm rice issue. One grower suggested, "we're not far enough along to understand how to set a safe zone [and] how to test for that zone...." (interview, November 2004). Concerned growers used market impacts as political leverage to enlist support to block pharm rice.

Second, activists' political and legal efforts convinced the Secretary of Food and Agriculture to prohibit the pharm rice by highlighting the difficulty of absolute containment. Anti-GE activists stressed the hazard's severity and likelihood, documenting the case of Prodigene where a soybean crop was contaminated with corn designed to produce a pig vaccine. The case illustrated how even stringent federal oversight of pharm crops is prone to mistakes. A similar "mistake" in California's rice industry would have far more devastating economic repercussions.

The activities of this industry-social movement alliance helped make precautionary cases for stronger regulation. The contamination argument mobilized by anti-GE activists stirred up support from many California rice growers who saw genetic pollution in economic terms; in turn, quotes from growers in the media carried much more authority than claims from activists on these matters typically do. A front page 
quotation in the San Francisco Chronicle from a story titled "California Rice Growers Fear Biotech Incursion" opened with a George W. Bush-supporting, duck-hunting rice farmer saying, "One little slip, one slip, that's all its gonna take" (Garofoli 2004).

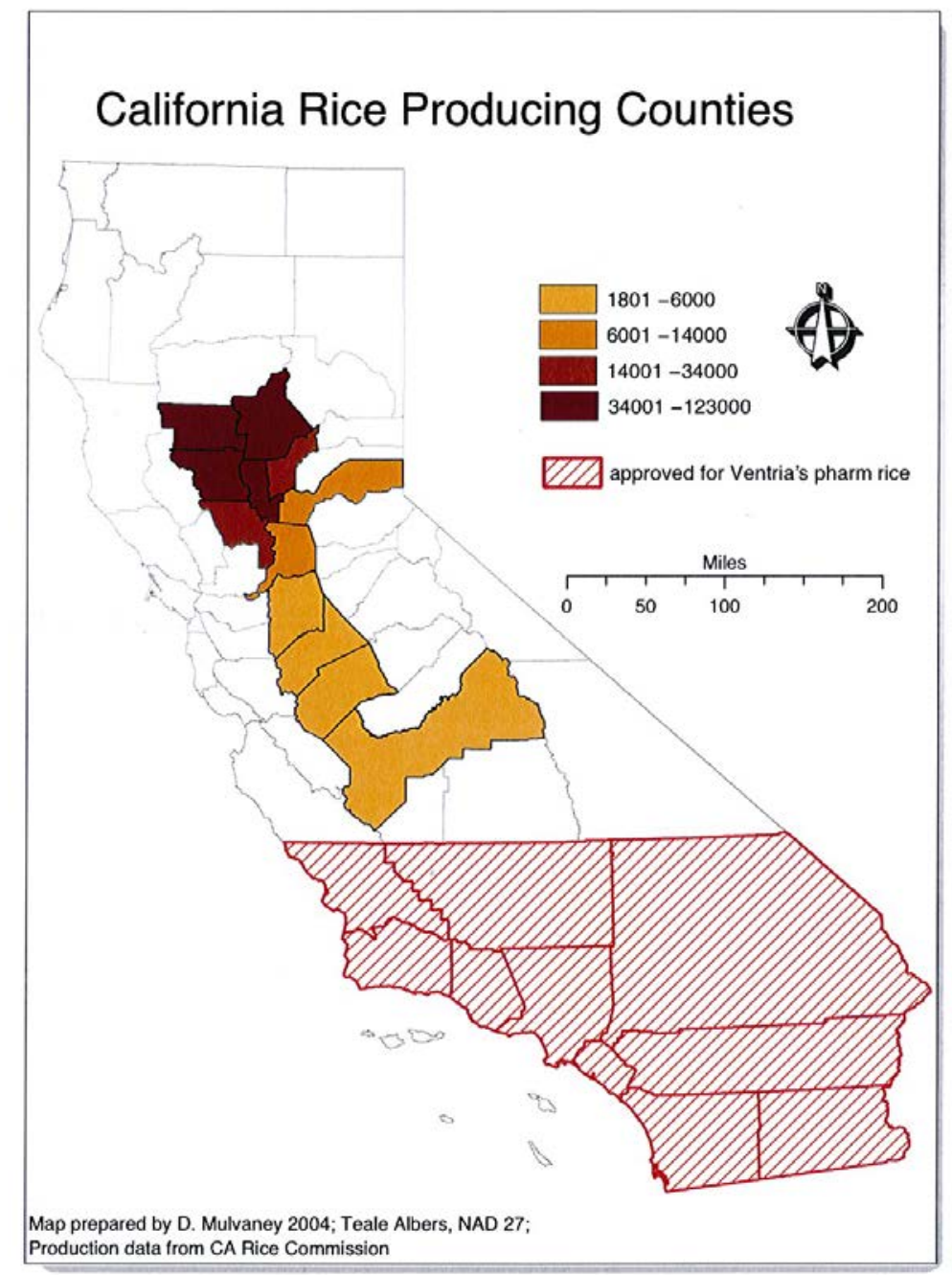

Figure 3: Geographical containment of GE pharm rice from California rice producing counties.

While anti-GE activists oppose GEOs based on a broad range of social and environmental dimensions, their coalition with growers cast the debate in terms of catastrophic market closures, giving activists greater leverage to support claims about the consequences of contamination. Not only did concerns about market losses generate support from rice growers, but these market concerns also created a statutory obligation that the CDFA would have to act on. By pressuring the Secretary of Agriculture and underscoring the state's responsibility to protect the economic interests of growers, anti-GE activists presented a convincing argument for why pharm rice should be kept out of commercial production. Market concerns were used as a surrogate for environmental and human health issues.

\section{Regulating transgenic fish: trojan genes in the waters?}

Transgenic aquaculture and fish farming is another controversial intersection of containment politics. Proponents argue that a new "blue revolution" of fish farming could relieve pressures on declining wild fishery stocks as consumer demand for seafood rises. Detractors cite serious ecological and human health 
issues including sea lice infestations, pollution from concentrated fish farms, competition from escaped fish, unsustainable rates of fish feed use, and high mercury and PCB levels in farmed fish. Transgenic aquaculture is promoted as a solution to the problems of fish farming by lowering feed-to-fish ratios and reducing pollution, but it raises additional questions about the effects of fish escapes on marine ecosystems.

Experimentation with transgenic fish began in the mid-1980s. The first transgenic fish was patented in the US in 1996, and in 2000 A/F Protein (now Aqua Bounty) first applied to the FDA for commercial approval of growth-enhanced transgenic salmon. The US, China, and Cuba have developed several transgenic fish, but the only species currently approved for commercialization in the US is a transgenic zebrafish that glows under a blacklight. The FDA declined to regulate the "GloFish" because it is not intended as food, but as of January 2013 it is still considering the Aqua Bounty application to deregulate their transgenic salmon.

The transgenic Atlantic salmon (Salmo salar) under consideration has been engineered for faster growth. The developers have promoted its introduction into net-pen, marine aquaculture, by pointing to the benefits of decreased residence time and increased food efficiency. Opponents, however, have suggested that it poses serious ecological risks, many of which are analogous to risks from the cultured Atlantic salmon currently used in commercial aquaculture (Naylor et al. 2005; Jonsson and Jonsson 2006). Additionally, scientists cannot "rule out the possibility that some transgenic fishes will pose greater ecological risk than fishes whose endogenous genes have been simply recombined through artificial selection, hybridization of closely related species, or ploidy manipulation" (Kapuscinski and Hallerman 1991: 101). Transgenic fish pose no new categories of ecological risk compared to conventional farmed fish, but they may have heightened ecological fitness as the ability to incorporate novel traits suggests they have an increased "evolutionary potential" (Kapuscinski et al. 1999: 13).

Ecological fitness is "the success in survival and reproduction of an individual organism, a population, or a species, relative to other individuals, populations, or species" (Scientists' Working Group on Biosafety 1998: 149). Salmon escapees from aquaculture farms compete with wild salmon for mating partners and with both wild salmon and other species for food and habitat. Farmed salmon escapees may successfully displace wild individuals (Naylor et al. 2005; Volpe et al. 2000). This is particularly important because of other pressures that endangered and threatened salmon populations face, like disease, urban and agricultural run-off, dams, increased water temperature, ocean acidification, and sedimentation. Salmon that mature more rapidly could also affect wild populations by establishing territories previously occupied by slower-growing wild salmon or attracting mates more successfully because of their greater size at sexual maturity. Faster growing salmon might also affect food resource availability. Establishment of feral transgenic salmon populations could amplify these competitive effects by increasing the rate and likelihood of interactions between feral and vulnerable native wild populations. Gene flow and introgression of transgenic salmon traits into wild stocks could have ecological fitness effects (Muir and Howard 1999; Muir and Howard 2001; Howard et al. 2004). It is possible that transgenic salmon could have lower fitness, and therefore be a minimal risk for long-term establishment (the concerns about competition for food by escapees would still remain); however, they could have equal or greater fitness, in which case the transgenes would introgress into the gene pools of wild salmon. Muir and Howard (1999) hypothesized that short-term beneficial fitness effects could be coupled with long-term negative fitness effects, leading to population extinction. They called this the "Trojan gene" effect.

The importance of salmon to California has made these issues even more controversial. Salmon are a "charismatic megafish," an iconographic species traditionally vital to Native populations. Salmon were an important food source during the Gold Rush, as an economic resource and employment opportunity for fishermen and cannery workers, and more recently as a popular sport fish. But the popularity of salmon, along with pressure from logging, mining, dams, and agriculture, has put them under threat. From 2008 through 2010, the California salmon fishing season was cancelled altogether due to drastic population decline. Salmon aquaculture poses yet one more danger to wild salmon.

While commercial fishing in California remains an important industry, aquaculture continues to be more marginal. The California Aquaculture Association (CAA), the state's aquaculture lobbying organization, includes onshore finfish, farmed caviar, and shellfish growers. A former CAA representative described aquaculture in California: "I don't know if it will ever be a significant industry... [But] it's the only place to get striped bass, catfish, sturgeon...A burgeoning caviar industry with sturgeon... [is] saving fish from the Caspian Sea. There is a very strong environmental advantage with that..." (interview, July 2005). This informant also suggested that salmon aquaculture is not a CAA priority, because: "...raising salmon at the scale that they are doing it in Chile and [British Columbia] and elsewhere is not going to be considered sustainable. And if you can't raise them at that scale it is not going to be economically viable" (interview, July 2005). Nonetheless, the prospects of transgenic salmon commercialization raised concerns among California's environmental and fishing community activists.

In 2001, a coalition of marine conservation NGOs met with legislative staffers, including from California Senator Sher's office, to set priorities for the upcoming session. The group included representatives 
of national and state environmental and commercial fishing organizations. Discussions initially focused on labeling legislation for aquaculture products. One environmental NGO representative said:

We looked at what the problem was and how it could be fixed, and we found that the best way to fix the problem was to give information to people, and then the advocacy groups could do the advocating on which information is good and which information is bad. ... You put the facts in front of someone and you take your seafood card and you say, 'Oh, this label says farm-raised salmon, oh, this group says don't eat that' and they match up. (interview, April 2005)

Labeling appeared to be a silver bullet: it could support local commercial fisheries and minimize aquaculture's negative consequences so long as consumers make informed decisions. Some expected that mandatory labeling would render transgenic fish unappealing to consumers, letting market forces drive transgenic salmon out of business.

Senator Sher's staff suggested, however, that legislation prohibiting the introduction of transgenic fish could be more politically feasible and effective. Several troubling findings had recently drawn negative attention to GEOs: experiments showing that Bt corn pollen harmed Monarch butterflies (Losey et al. 1999); the presence of StarLink corn, not FDA approval for human consumption, in taco shells in grocery stores (Segarra and Rawson 2001); and the discovery of transgenic traits in maize landraces in Mexico, the center of maize genetic diversity (Quist and Chapela 2001). The media also highlighted problems with industrialized salmon aquaculture. A Mother Jones story, "Aquaculture's Troubled Harvest" (Barcott 2001), about salmon farming in the Pacific Northwest, sparked the interest of Senator Sher's staff. Transgenic salmon and the potential extinction of wild salmon had also recently garnered headlines with the publication of the Trojan gene hypothesis (Muir and Howard 1999).

With Senator Sher's staff's input, the NGO coalition pressed forward with both the labeling proposal and transgenic aquaculture ban. But labeling met a swift demise in the Assembly Committee on Agriculture, where opposition from the Grocery Manufacturers' Association and Monsanto sounded its death knell. The proposal for a ban faced opposition from important players, particularly the CAA, the University of California, and Aqua Bounty. Despite Senator Sher's sponsorship, it also died in committee. The NGO coalition, however, remained committed to pursuing a ban and sought other avenues to achieve it; in particular, regulation at the California Fish and Game Commission (FGC).

According the FGC, "there were several people who were concerned about the failure of Sher's legislation and the fact that we didn't have any statutory or regulatory language on the books that would somehow limit of control transgenic organisms" (interview, July 2005). In an attempt to achieve consensus among the parties involved, the Commission formed a transgenic aquaculture working group, and assigned agency staff to coordinate its activities.

The group convened its first "transgenic workshop" in November 2002, with the goal of defining terms and recommending regulatory changes to the Fish and Game Code. A representative from the FGC said of the process, "What was unique about that was that it included environmental groups, academia, the aquaculture industry, and government agencies. They all got together. They talked to each other" (interview, July 2005).

The participants came from diverse backgrounds, which explains why they described it as a focus group rather than an "expert committee." They included NGO representatives from groups such as National Resource Defense Council, Center for Food Safety, and Institute for Fisheries Resources; University of California and California Sea Grant scientists and administrators; commercial aquaculturists from Kent SeaTech and Scientific Hatcheries; and FGC staff.

After the initial meeting, the group communicated via e-mail and telephone over the next several months aiming to achieve consensus on regulatory language and to define the term "transgenic." Drawing on a definition from the Organic Production Act of 1990, they eventually arrived at a definition adopted into the California Code of Regulations in 2003:

Genetically altered by introducing DNA (1) from another species or (2) through engineered endogenous constructs by means such as but not limited to recombinant DNA and RNA techniques to produce, gene addition, deletion, and doubling, or changing the position of the gene. This definition excludes DNA vaccines, individuals produced by the techniques of whole genome ploidy manipulation, and hybridization between closely related species, as in traditional hybridization. (CCR Title 14, Division 1, Subdivision 1, Chapter 1, §1.92)

The process of adopting a definition, one NGO participant said, was very difficult: "How do you translate science into law?" (interview, April 2005). According to one scientist, "the rule that got developed 
was definitely a 'consensus rule.' As a pure scientist, some of the definitions and things were not exactly what I would have written" (interview, May 2005).

Many scientists prefer regulations based on an organism's physical characteristics rather than the method used to produce it; still, most of the group members were content with the rules. The CAA representative said the compromise was satisfactory: "I guess it lacked some of the scientific rigor that you would want to have, but was very difficult to get. There is some level where you have to be pragmatic, political, in terms of the compromise" (interview, July 2005). The environmental organizations were generally pleased with the outcome, because it addressed the containment issue. "Our goal was not that there had to be an onerous burden [to get a permit], but to make sure that we had this regulatory program in place," said a national environmental NGO representative involved from the beginning of the process (interview, July 2005).

An FGC representative responsible for working with the group described the process as successful, beginning with the inchoate and leading to a good regulation:

This process started well before any regulatory language was developed. After the first meeting we didn't have any specific language at all, just general concepts and ideas. ... It was an amazing process. After it was done we couldn't believe that actually we pulled it off and that everybody felt pretty good about it. ...[B]asically people felt that, in terms of environmental protection, the process worked. (interview, April 2005)

Despite their satisfaction with the resulting regulation and process, the NGOs still had not achieved a ban on transgenic aquaculture. In a comment that resonates with characterizations of GM fish as "Frankenfish" and asserts that experiments should be strictly contained, one NGO representative said, "We don't want your experimental design swimming around..." (interview, April 2005). The coalition eventually decided to continue to pursue legislation. Senator Sher introduced SB 245 in February 2003 to amend the aquaculture section of the California Fish and Game Code to make it "unlawful to spawn, incubate, or cultivate any species of finfish belonging to the family Salmonidae, transgenic fish species, or any exotic species of finfish" (California Fish and Game Code Section 15007 (a)).

With the debate over definitions resolved, the process of passage was far simpler. Because the regulations had according to a former NGO representative, "gotten sign off" from people originally opposed to the legislation, "we pretty much had all the reasonable stakeholders" (interview, April 2005). That the Bill first went to the Senate Natural Resources Committee helped as well. According to a fishermen's NGO representative, "Natural Resources has tended to be a much easier, much more friendly committee on fisheries issues and environmental issues" (interview, April 2005).

The academic community, too, was more comfortable with the language in SB 245. One representative of the University of California legislative office even said, "I think SB 245 is a great example of a piece of legislation that had the unintended consequence of raising people's awareness about the issue that would never had come out," and added, "The process was a good one because we got campuses examining their research protocols" (interview, May 2005).

Most of the opponents of the earlier bill either supported SB 245 or sat out of the hearings. One aquaculturalist suggested that aquaculture businesses were willing to give in on this issue because they did not see any immediate business impacts and therefore did not want to expend time, energy, and legislative good will:

[The CAA] was willing to sacrifice our issues to other issues, and people were willing to go along with that, again because there's no spokesperson for the uninvented. Nobody in the CAA had permits up to do an offshore aquaculture program in California. And so nobody was planning to do it, and so nobody had a vested interest in it, and so there was no spokesman for the uninvented....(interview, July 2005)

A former CAA representative noted that opposition came mainly aquaculture groups from outside California, because they feared the reaction might spread:

There was very strong resistance to our position by the Canadian Aquaculture Association [and]...by the folks who have the application in on the east coast...they hired separate lobbyists. I went up to speak to their association and I thought I was going to get lynched! They [worried] that other states would follow our lead and start banning salmon aquaculture. (interview, April 2005) 
A more typical reaction was that of a former NGO representative: "For right now, it does what it is supposed to do.... [It] sent a strong message [and] ... it kind of closes California's door to genetically modified fish, so I think it does the job there" (interview, April 2005).

The process in California passed through several phases. First, it involved creating a coalition with environmental and commercial fishermen's NGOs and legislative and agency officials. This group pressed forward in the face of initial setbacks, in part by creating consensus with and assuaging the concerns of academic researchers as well as local industry groups while marginalizing external industry groups and avoiding unfriendly legislators by turning to a regulatory strategy. By the time legislation was reintroduced, shifting legislative constellations and a lack of opposition, along with strong local support, cleared the way for easy passage. A flexible, adaptable strategy took advantage of policy opportunities to create strong containment policies.

\section{California's policy-making effect?}

California was not a surprising venue for subnational activity on either transgenic aquaculture or pharm rice. The state is progressive on environmental issues, often setting standards that the federal government subsequently adopts. Both agriculture and fisheries are economically important here, and industry, activist, and producer organizations are active in state ocean and agriculture policy. California has the advantage of close working relationships with NGOs working on ocean policy issues. The state already passed legislation banning open ocean finfish aquaculture and legislation addressing invasive species. The legislation ban on transgenic aquaculture is an extension of those two issues. This combination of an existing working group, an amenable regulatory and legislative environment, and California's strong coastal and marine protection policies, made it a likely site for this intervention.

Nonetheless, it is still worth asking why activists sought to regulate this issue at the state scale, rather than federally. Fish do not recognize political borders, and any gains achieved through California-specific legislation could be lost through activities in neighboring states, or countries. Legislation could, however, encourage similar action by other states or the federal government. One NGO representative said, "I thought if we could do it here in the state we could set a precedent and then we could say look, look, this is what California's done" (interview, April 2005). Also, California's sheer size, "...on the West Coast, [California has] two thirds of the coastline of the Pacific contiguous states, so you can make a big difference in coastal and oceanic issues just by taking action in California" (interview, April 2005). Indeed, considering the Washington Department of Fish and Wildlife regulatory ban on transgenic aquaculture, and Alaska's outright ban on commercial aquaculture, Oregon has the only coastline in the Western states open to transgenic aquaculture (although Oregon has banned transgenic salmon). In addition, by limiting the possible sites for transgenic aquaculture, bans such as California's can indirectly make transgenic fish commercialization less attractive to industry. On the other hand, industry suggests that regulation would simply displace transgenic fish to other countries, such as Chile, as has already occurred with salmon aquaculture more broadly.

Many participants in the process explained that the primary motivation for acting at the state level was because action was possible. One informant said, "it would have never happened... at the federal level," and added that action in one state can provide another state with the impetus to act as well (interview, July 2005). This NGO representative added that there are "only so many states you can conduct aquaculture in anyway," and that by closing any state to transgenic aquaculture, it makes transgenic fish commercialization less viable. The informant said that the Washington regulations provided California with cover, and that acting at the state level in California was "politically feasible," but that the "big goal" is eventually to have similar legislation adopted nationwide, because the NGO community "isn't necessarily opposed to GEOs, it's just that we don't want them in the ocean" (interview, April 2005)

The emergence of regulatory framework for GE rice in California was not surprising either. The industry is one of the more progressive on other environmental matters such as air pollution generated from burning rice straw and water pollution from agrochemicals. The California Rice Commission has been politically active since its creation in the late 1990s, partly because of the rice industry's high visibility and proximity to Sacramento.

The California rice industry also wanted to demonstrate a proactive approach to GE rice regulation. One industry official was clear in saying, "we had to show Japan, hey... we've got this under control, long before any transgenic rice is destined for market" (interview, November 2005). Japan is required to purchase a minimum amount of rice from the US every year because of a concession made at the 1994 Uruguay Round of the World Trade Organization. Most of this rice is stored in government warehouses until it is exported as food aid or used for biofuels. One might imagine that if Japan could find an excuse to stop buying California rice, or affect the market price, it would do so. With the federal approval of an herbicide tolerant rice variety in 1999, the industry had to take action before the rice could be grown commercially. It is no surprise that an industry engaged in the "thin, risky, and volatile" rice trade was proactive on an issue that could be easily turned into a trade barrier (Economic Research Service 2001). 


\section{Were these outcomes a success?}

California's governance of GE salmon and GE rice can be considered successes insofar as they show states' capacity to regulate the release of particularly risky GEOs. California's interventions give activists and scientists more time to evaluate the consequences of such releases. These policies also fill perceived regulatory voids, adopting a precautionary policy in the face of uncertainty about federal rules.

These policies also forced biotechnology firms to reassess their future in California. Ventria knew that the rice industry had to be both accommodating and antagonistic to the plan to introduce pharm rice. In late 2004, Ventria signed a contract with the University of Missouri to grow rice there, but soon found itself in another standoff. Budweiser, the largest purchaser of Missouri rice, said it would no longer purchase rice from Missouri if the state approved the pharm rice. Ventria now grows pharm rice in North Carolina, far from any significant commercial rice production. But continued threats may force Ventria to move to a country with more lenient rules. If pharm rice is commercialized in a developing country with lax oversight, then the CDFA ruling could compromise food safety more than maintain it; pharm rice could end up in imports. Though such a move requires significant investments and may be a rhetorical threat more than a realistic alternative.

One aspect of the CRCA that might be seen as a success is how it fills a Federal regulatory void by focusing on market risks. Neither the USDA-APHIS, the EPA, nor the FDA cite market concerns in GEO regulatory decisions; their purview is limited. In GE corn and GE soy, early adopters reaped the benefits, while passing the economic risks onto neighboring fields or growers vulnerable to contamination. The CRCA expands the considerations to include market risks, and in so doing provides leverage for those with wider concerns about GEOs.

The California fish story similarly relied on a particular alignment of actors. Fish and Game regulations for transgenic fish provide proactive assurances that the Trojan gene hypothesis will not be tested in state waters. However, since open ocean aquaculture is currently prohibited in California waters, it is unclear whether transgenic finfish like salmon would ever be grown. For a transgenic salmon to legally enter California waters would require changes to federal rules for offshore aquaculture. As currently proposed, offshore aquaculture would be governed by federal rules and provide little space for states to intervene, something states would be reluctant to accept.

\section{Best practices}

These two cases share a number of similar characteristics that fostered a state-led regulatory approach: significant economic risk potential, economically and culturally important impacts, and less pronounced power asymmetries than in other GE crops like corn and soy. Proponents of GEO commercialization were not the powerful actors described in typical anti-GE activist narratives and had to give in to a strong precautionary approach to containment. Markets for both commodities are also particularly susceptible to consumer pressure: the Asian markets for rice are strongly opposed to GE foods, and fish is particularly subject to heightened consumer concerns.

For these reasons, pharm rice in California is not commensurable with pharm corn in Iowa. Nor is transgenic aquaculture in a state with an important commercial ocean fishing sector as easily accepted as the USDA-approved, GE herbicide tolerant cotton widely adopted by California cotton growers. There are other commodities that are similarly entangled. Many US wheat producers are chary of GE wheat because of the anti-GE European and Pacific Rim export markets, and farmers in North Dakota sought state-level action to prevent contamination of conventional wheat by GM wheat (Olson, 2005). Hawaii in 2008 considered legislation to protect both commercially-important Kona coffee and culturally-important taro, and both Hawaii and Maui counties have banned GE taro cultivation from their islands. Activists in Colorado have tried to carve out a role for state regulation of pharm crops because of particular concerns about the reputation of local sweetcorn (Taylor et al. 2004). So while the location and the commodities are in many ways uniquely suited to sub-national regulatory approaches, these two cases still provide lessons and insights for other products and places.

In the case of transgenic aquaculture, activists felt that federal regulation, under the aegis of the FDA, was inadequate for addressing the ecological consequences of fish escape. Concerns about gaps or inadequate regulation at the federal level, combined with a sense that "... we thought we could do something here and then doing it at the state level would give us a leg up to start trying to do it federally," as an NGO actor put it (interview, July 2005), meant that activists targeted the state level for action. The state provided a policy forum that was closed at the federal level, where the approval process for transgenic salmon remained quite literally closed due to confidential business information concerns.

In the case of pharm rice, specific economic and environmental concerns made a state-based approach possible. California rice growers now have a significant level of control over GE rice deployment as they add their own expertise about legitimate risks. Migrating ducks became unruly actors in the proposed containment 
management scheme, as a duck's potential to turn GE seeds into GEO contamination underscores the challenges of containment.

Local regulation allows actors to address issues that are precluded at the federal level, but does have limitations. A lack of scientific, technical, and economic resources means that adequate management and enforcement may not be possible. Yet, where the legislative interest and resources exist, activists can use subnational venues to open the process, encourage more public participation, and reduce power and information asymmetries (see Weil 2013). However, full-fledged governance institutions, with public participation, and a broad public health and environmental agenda, are still far off.

\section{Conclusion}

The U.S. regulatory system for GEOs is an ex post system, with GE agriculture considered substantially similar to conventional agricultural practices and few precautionary elements included (Welsh and Ervin 2006). With a lack of post release monitoring by regulatory agencies, this means that the premise of controlling problems after they are discovered is flawed. When the potential consequences of release are particularly troubling, as with escaped transgenic fish into sensitive ecosystems or accidental release of pharm crops into the food system, a precautionary approach requires understanding the likelihood of containment, and the impacts of even low level gene escape. Where absolute containment is required but not possible, activists and officials have sought regulatory responses ranging from strict permitting and monitoring processes to moratoria and outright bans.

A politics of containment can also be a tactic to discourage GEOs altogether, especially if it drives costs beyond commercially viability. For example, achieving levels of triploidy in fish close to $100 \%$ incurs a significant loss of fish eggs, making the practice unlikely to be commercially viable for fish egg producers. Likewise, a catastrophic containment failure can be used to justify not growing risky crops; activists need not be concerned with markets at all, only tactically exploit those political opportunities and industry vulnerabilities. Hence helping subnational regulation take root is a mixture of internal factors-the motivations and efforts of anti-GE activists - and external factors - the multiple interests that mobilized broad coalitions and public support. Commercial interests, consumer choice questions, culture, identities, and traditions, and ethical and moral concerns all entered state and local processes in ways not possible in the narrowly defined bounds of the Coordinated Framework. These are prospects that leave us hopeful.

By 2007 precaution was pushed even further in California's rice and aquaculture industries. The California rice industry, on the heels of an economically disastrous GE contamination incident for growers in the US Southeast, passed a moratorium on commercial GE rice adoption. This was a recognition that absolute containment is far too challenging to manage especially in light of potentially catastrophic consequences. Until buyers are willing to tolerate a certain level of GE traits in food, it is unlikely GE rice will take root in any significant way (Mulvaney, Krupnik and Koffler 2011).

California has also taken steps to regulate fish farming with the Sustainable Oceans Act of 2006. This gave much broader power to regulate the fish farming in the state. This powerful tool could improve the oversight of controversial practices used in industrial aquaculture.

But perhaps where anti-GE actions offer the most hope is outside the formal risk policy arena. Anti-GE activism is also changing the trajectory of agricultural research both inside genetic engineering practices, as, for example, with open source biotechnology, and outside them, by advocating local food sheds and sustainable agriculture on agro-ecological principles. These are reactions to existing trends and paradigms, much as Polanyi might anticipate. While activists seek to regulate industrial agriculture and its attendant risks, they also promote alternative paradigms. The seeds that anti-GE activists sow in resistance to GEOs take root as precautionary policies as they open and occupy new spaces for alternatives. 


\section{References}

Andow, D., K. Lamkey, H. Daniell, E. Nafziger, P. Gepts and D. Strayer. 2004. A growing concern: protecting the food supply in an era of pharmaceutical and industrial crops. Washington, DC: Union of Concerned Scientists.

Barcott, B. 2001. Aquaculture's troubled harvest. Mother Jones Nov/Dec.

Barnes, R. 2013. Farmer's use of genetically modified soybeans grows into Supreme Court case. The Washington Post February 102013.

Berg, P., D. Baltimore, S. Brenner, R. Roblin III, and M. Singer. 1975. Summary statement of the Asilomar Conference on recombinant DNA molecules. Proceedings of the National Academy of Sciences 726: 1981-1984.

Berkeley City Council. 1999. Regular Berkeley City Council meeting consent calendar item: growing, disseminating, and marketing products containing genetically-engineered organisms.

Retrieved December 17, 2012, from

http://www.ci.berkeley.ca.us/citycouncil/1999citycouncil/summary/120799s.html.

Bisbee, D. 1993. Preparing for a blue revolution: regulating the environmental release of transgenic fish. Virginia Environmental Law Journal 12: 625.

Bok, D. 2003. Universities in the marketplace: the commercialization of higher education. Princeton: Princeton University Press.

Borlaug, N. 2000. Ending world hunger: the promise of biotechnology and the threat of anti-science zealotry. Plant Physiology 124: 487-490.

Brown, H. and R. Goble 1990. The role of scientists in risk assessment. Risk Issues in Health and Safety: VI: 283-311.

California Fish and Game Code Section 15007 (a) Retrieved February 12, 2013, from http://www.leginfo.ca.gov/cgi-bin/displaycode?section=fgc\&group=14001-15000\&file=15000-15008

CCR Title 14, Division 1, Subdivision 1, Chapter 1, §1.92 Retrieved February 12, 2013, from https://law.resource.org/pub/us/ccr/gov.ca.oal.title14.html

Cleveland, D.A. and D. Soleri 2005. Synthesis: rethinking the risk management process for genetically engineered crop varieties in small-scale, traditionally based agriculture Ecology and Society 101: 941.

Craik, N., K. Culver, N. Siebrasse. 2007. Genetically modified crops and nuisance: exploring the role of precaution in private law. Bulletin of Science, Technology and Society 273: 202-214.

Daniell, H. 2002. Molecular strategies for gene containment in transgenic crops. Nature Biotechnology 20: 581-586.

Deeter, S. 2005. Prepared remarks of Mr. Scott Deeter for the different applications for GM Crops hearing, Subcommittee on Rural Enterprises.

Retrieved July 5, 2005, from http://www.plantpharma.org/2005/07/prepared-remarks-of-mr-scottdeeter-for-the-different-applications-for-genetically-modified-crops-hearing/.

Devlin, R., C. A. Biagi, T. Yesaki, D. Smailus, J. Byatt. 2001. Growth of domesticated transgenic fish. Nature 409: 781-782.

Devlin R., L. Sundström, and W.M. Muir. 2006. Interface of biotechnology and ecology for environmental risk assessments of transgenic fish. Trends in Biotechnology 243: 89-97.

Economic Research Service. 2001. Briefing Room: Rice Background. Retrieved December 20, 2004, from http://www.ers.usda.gov/briefing/rice/background.htm.

Editorial 2004. Drugs in crops-the unpalatable truth. Nature Biotechnology 222: 133.

Garofoli, J. 2004. State's rice farmers fear biotech incursion: proposal for genetically engineered crop could threaten lucrative foreign markets. San Francisco Chronicle. 8 April.

GeneWatch UK \& Greenpeace International. 2010. GM Contamination Register. Retrieved January 15, 2010, from http://www.gmcontaminationregister.org.

Geniella, M. 2004. Mendocino County voters ban biotech crops. Santa Rosa Press Democrat Retreived December 17, 2012 from http://gefreevt.org/index.php?name=news\&ID=115

Griffin, K. 1974. The political economy of agrarian change: an essay on the Green Revolution. Cambridge, MA: Harvard University Press.

Grossman, M.R. 2002. American law in a time of global interdependence: U.S. National Reports to the XVIth International Congress of Comparative Law: Section II Biotechnology, Property Rights and the Environment. American Journal of Comparative Law 50: 215-248.

Heller, C. 2003. Risky science and savoir-faire: peasant expertise in the french debate over genetically modified crops. In M. Lien and B. Nerlich (eds.) The politics of food. New York: Berg Publishers. Pp. 88-101. 
Holt Mueller, M. and A. van der Valk 2002. The potential role of ducks in wetland seed dispersal. Wetlands 221: $170-178$.

Howard, R., J. DeWoody, W. Muir. 2004. Transgenic male mating advantage provides opportunity for Trojan gene effect in a fish. Procedings of the National Academy of Sciences 1019: 2934-2938.

Jonsson, B. and N. Jonsson 2006. Cultured Atlantic salmon in nature: a review of their ecology and interaction with wild fish. Journal of Marine Science 637: 1162-1181.

Kapuscinski, A. and E. Hallerman 1990. Transgenic fish and public policy: anticipating environmental impacts of transgenic fish. Fisheries 121: 2-11.

Kapuscinski, A., T. Nega, and E. Hallerman 1999. Adaptive biosafety assessment and management regimes for aquatic genetically modified organisms in the environment. Rome: FAO.

Kenney, M. 1986. Biotechnology: the university-industrial complex. New Haven: Yale University Press.

Kevles, D. 1998. Diamond v. Chakrabarty and beyond: the political economy of patenting life. In A. Thackrey (ed.) Private science: biotechnology and the rise of molecular sciences. Philadelphia: University of Pennsylvania Press. Pp 65-79.

Kloppenberg, J. 2004. First the seed: the political economy of plant biotechnology. Madison: University of Wisconsin Press.

Krimsky, S. 1982. Genetic alchemy: the social history of the recombinant DNA controversy. Cambridge, MA: MIT Press.

Lacy, W. B. 2000. Commercialization of university research brings benefits, raises issues and concerns. California Agriculture 544: 72-79.

Lee, M. and R. Burrell 2002. Liability for the escape of GM seeds: pursuing the victim? The Modern Law Review 654: 517-537.

Liebert, M. A. 2006. Regulatory affairs: agricultural and environmental. Biotechnology Law Report 252: 148-151.

Lockie, S. 'The invisible mouth': mobilizing 'the consumer' in food production-consumption networks. Sociologia Ruralis 42(4): 278-294.

Logar, N. and L.K. Pollock 2005. Transgenic fish: is a new policy framework necessary for a new technology? Environmental Science and Policy 8: 17-27.

Losey, J., L. Raynor, M. Carter. 1999. Transgenic pollen harms monarch butterflies. Nature 399: $214-215$.

Marvier, M. 2001. Ecology of transgenic crops. American Scientist 89: 160-167.

Marvier, M. and R. Van Acker 2005. Can crop transgenes be kept on a leash? Frontiers in Ecology 32: 99106.

McGloughlin, M. 2001. Public perceptions of agricultural biotechnology: a nonsocial science perspective. Medical Anthropology Quarterly 151: 34-37.

Mooney, P. R. 1983. The law of the seed: another development and plant genetic resources. Development Dialogue 1-2: 1-173.

Muir, W. and R. Howard 1999. Possible ecological risks of transgenic organism release when transgenes affect mating success: sexual selection and the Trojan Gene hypothesis. Proceedings of the National Academy of Sciences 9624: 13853-13856.

Muir, W. and R. Howard 2001. Fitness components and ecological risk of transgenic release: a model using Japanese Medaka Oryzias latipes. The American Naturalist 1581: 1-16.

Mulvaney, D., T. Krupnik, and K. Koffler. 2011. Transgenic rice evaluated for risks to marketability. California Agriculture 65: 161-167.

Nandi, S., D. Yalda, S. Lu, Z. Noikolov, R. Misaka, K. Fujiyama and N. Huang. 2002. Process development and economic evaluation of recombinant human lactoferrin expressed in rice grain. Transgenic Research 143: 237-249.

National Research Council 2002. Environmental effects of transgenic plants: the scope and adequacy of regulation. Washington, DC: National Academy of Sciences.

National Research Council 2004. Biological confinement of Genetically Engineered Organisms. Washington, DC, National Academy of Sciences.

Naylor, R., K. Hindar, Ian Fleming, R. Goldburg, S. Williams, J. Volpe, F. Whoriskey, J. Eagle, D. Kelso and M. Mangel. 2005. Fugitive salmon: assessing the risks of escaped fish from net-pen aquaculture. Bioscience 555: 427-438.

Newell-McGloughlin, M. and E. Re 2006. The evolution of biotechnology. Dordrecht: Springer.

Office of Science and Technology Policy. 1986. Proposal for a coordinated framework for regulation of biotechnology. Federal Register 51: 23302-23393.

Organic Consumers Association. 2004. Press release on Marin County ban on GE crops. Retrieved February 10, 2005, from http://www.organicconsumers.org/biod/marin110304.cfm. 
Olson, R. 2005. Hard red spring wheat at a genetic crossroad: rural prosperity or corporate hegemony? In D. L. Kleinman, A. Kinchy and J. Handelsman. (eds.) From maize to menopause. Madison: University of Wisconsin Press. Pp 150-168.

Pamer, M. 2004. Prescription rice: the brave new world of pharma-foods. Terrain Summer: 10-13.

Pearse, A. 1980. Seeds of plenty, seed of want: social and economic implications of the Green Revolution. Oxford: Clarendon Press.

Pew Initiative on Food and Biotechnology. 2003. Legislation Tracker 2003. Retrieved November 10, 2004.

Polanyi, K. 1944. The Great Transformation: the political and economic origins of our time. Boston: Beacon Press.

Potrykus, I. 2001. Golden Rice and Beyond. Plant Physiology 125(3): 1157-1161.

Quist, D. and I. Chapela 2001. Transgenic DNA introgressed into traditional maize landraces in Oaxaca, Mexico. Nature 414: 541-543.

Raffensperger, C. and J. Tickner (eds.). 1999. Protecting public health and the environment: implementing the precautionary principle. Washington, D.C.: Island Press.

Rajan S.R. and C.A.M. Duncan. 2013. Ecologies of Hope: environment, technology and habitation - case studies from the intervenient middle. Journal of Political Ecology 20: 70-79.

Rodgers, C.P. 2007. Coexistence or conflict? A European perspective on GMOs and the problem of liability. Bulletin of Science, Technology and Society 273: 233-250.

Scientists Working Group on Biosafety. 1998. Manual for assessing ecological and human health effects of GEOs. Retrieved December 15, 2006, from http://www.edmonds-institute.org/manual.html.

Segarra, A. and J. Rawson 2001. StarLink corn controversy: background. Economic Research Service. Washington, D.C.: Congressional Research Service.

Smith Hughes, S. 2001. Making dollars out of DNA: the first major patent in biotechnology and the commercialization of molecular biology. Isis 923: 541-575.

Taylor, M., J. Tick and D.M. Sherman. 2004. Tending the fields: state and federal roles in the oversight of genetically modified crops. Washington D.C.: Resources for the Future.

Ten Eyck, T., P.B. Thompson, and S. Priest. 2001. Biotechnology in the United States of America: mad or moral science? In G. Gaskell and M. W. Bauer (eds.). Biotechnology 1996-2000: the years of controversy. London: Science Museum. Pp 307-318.

Traavik, T. and L. Ching (eds.). 2007. Biosafety first: holistic approaches to risk and uncertainty in genetic engineering and genetically modified organisms. Trondheim: Tapir Academic Press.

Uchtmann, D.L. and G.C. Nelson. 2000. US regulatory oversight of agricultural and food-related biotechnology. American Behavioral Scientist 443: 350-377.

UNEP 1992. Rio Declaration on Environment and Development. Rio de Janeiro: United Nations Conference on Environment and Development.

Volpe, J., E. Taylor, D. Rimmer, B. Glickman. 2000. Evidence of natural reproduction of aquacultureescaped Atlantic salmon in a coastal British Columbia river. Conservation Biology 14: 899-903.

Weil, B. 2013. Solar city, bike city, growth city: governance and energy in Davis, California. Journal of Political Ecology 20: 137-158.

Weiner, C. 2001. Drawing the line in genetic engineering: self-regulation and public participation. Perspectives in Biology and Medicine 442: 208-220.

Welsh, R. and D. Ervin 2006. Precaution as an approach to technology development: the case of transgenic crops. Science, Technology and Human Values 312: 153-172.

Wright, S. 1994. Molecular politics: developing American and British regulatory policy for genetic engineering. Chicago: University of Chicago Press. 


\begin{abstract}
California has been an important site of governance on risks from genetically engineered (GE) organisms. This paper reviews California's efforts to govern the ecological and food safety risks from GE salmon and GE pharmaceutical rice. We explain how a political constellation of actors emerged to pursue precautionary policies, and we discuss the prospects for similar policies elsewhere. We find that regulation of particularly risky objects is possible in some places, particularly where social movement organizations are mobilized and the possible consequences are severe, such as with impacts to wild salmon runs or pharmaceutically contaminated foods. But such regulations may only emerge when they are inconsequential to, or aligned with, the market concerns of dominant economic interests.
\end{abstract}

Key Words: genetically engineered organisms, social movements, biosafety, California.

\title{
Résumé
}

La Californie a été un site important de la gouvernance des risques du génie génétique (OGM). Cet article passe en revue les efforts de la Californie pour régir les risques pour la sécurité écologique et alimentaire de saumon GE et riz pharmaceutique. Nous expliquons comment une constellation d'acteurs politiques a émergé à poursuivre des politiques de précaution, et nous discutons des perspectives de politiques similaires ailleurs. Nous trouvons que la réglementation des objets particulièrement risqués est possible dans certains endroits, en particulier là où les mouvements sociaux sont mobilisés et les conséquences possibles sont graves, tels que des impacts sur les saumons sauvages ou d'aliments contaminés pharmaceutique. Mais ces réglementations ne peuvent émerger quand elles sont anodines, ou aligné avec les préoccupations du marché des intérêts économiques dominants.

Mots clés: organismes génétiquement modifiés, les mouvements sociaux, la biosécurité, la Californie.

\section{Resumen}

California ha sido una importante área de gobernabilidad de riesgos provenientes de organismos genéticamente modificados (GM). Este artículo revisa los esfuerzos llevados a cabo por California para regular los riesgos ecológicos y para la seguridad alimentaria derivados de salmón GM y arroz farmacéutico GM. Explicamos cómo emergió una constelación política de partes interesadas para luchar por la implementación de políticas preventivas y discutimos la posibilidad de aplicar políticas similares en otros lugares. Concluimos que la regulación de objetos particularmente peligrosos es posible en algunos lugares, particularmente donde existen movimientos sociales activos y donde las posibles consecuencias son severas, tales como el impacto en las migraciones de salmones salvajes para desovar o los alimentos contaminados farmacéuticamente. Pero tales regulaciones sólo pueden emerger cuando no tienen consecuencias o se encuentran alineadas con las preocupaciones del mercado o los intereses económicos dominantes.

Palabras clave: organismos genéticamente modificados, los movimientos sociales, la bioseguridad, California. 